\title{
VARIEDADES
}

\section{¿SA'ĀDA = SA'ĀDA AL-'ĀMIRĪ? \\ (PRECISIONES EN TORNO A UN TRABAJADOR ANDALUSÍ DE LA CONSTRUCCIÓN) *}

\author{
JUAN A. SOUTO \\ Universidad Complutense
}

Tres capiteles de la ampliación de la Mezquita Aljama de Córdoba hecha por Almanzor lucen, cada uno en una cartela, el nombre (Sa'āda) muy bien inscrito ${ }^{1}$. Don Manuel Ocaña supuso que se trataba de un «vocablo propiciatorio aislado: Felicidad ${ }^{2}$. (...) Como sabemos, este vocablo va unido generalmente a otros similares, como Bendición, Prosperidad, Fortuna... etc., que se dedican, por lo común, a un determinado personaje para el que se desea que Dios le conceda tales dones. En este caso concreto, va aislado; pero su especial diseño, el peculiar de las trazas cúficas grabadas en resalto, denota que fue realizado por un cantero harto familiarizado con tales frases propiciatorias» ${ }^{3}$.

Al hacer la carta gliptográfica del monumento consideramos «Sa'āda» como un antropónimo y así lo clasificamos, proponiendo con ello (implícita y explícitamente) que las tres inscripciones en cuestión son otras tantas marcas de identidad del tallista de las piezas

\footnotetext{
* El presente trabajo se inscribe en el proyecto de investigación "Epigrafía y construcción en al-Andalus omeya", subvencionado por la Fondation Max van Berchem.

1 Son los capiteles que denominamos con las siglas C8, F1 y G30 (Rodríguez, $\mathrm{M}^{\mathrm{a}} \mathrm{J}$. y Souto, J. A., "De Gliptografía Omeya: signos lapidarios en la Mezquita Aljama de Córdoba. Situación e índice", Actes du XIe Colloque International de Glyptographie de Palma de Majorque, Braine-le-Château (2000), pp. 356, 370, 373 y 385). Esas siglas indican las coordenadas de las correspondientes columnas, y son las propuestas por Ewert, C., \& Wisshak, J. P., Forschungen zur almohadischen Moschee. Lieferung 1: Vorstufen, Maguncia (1981), passim y figuras 34 a 41, obra donde se podrá ver una magnífica síntesis histórica y morfológica del edificio.

2 Ocaña Jiménez, M., "Arquitectos y mano de obra en la construcción de la gran mezquita de Occidente", Cuadernos de la Alhambra, 22 (1986), 83.

3 Ídem, nota 20 de la página 84 . Hay una fotografia del calco de la inscripción del capitel $\mathrm{F} 1$ en la página $79, \mathrm{n}^{\circ} 309$
}

Al-Qantara XXIII, 2 (2002) 331-334 
donde se encuentran ${ }^{4}$. Sin embargo, no descartamos del todo la posibilidad de que se tratase de un vocablo propiciatorio ${ }^{5}$.

Hoy día estamos en condiciones de afirmar, creemos que con bastante certeza, que el nombre «Sa'āda» de los capiteles de la Aljama cordobesa es, efectivamente, un onomástico, y su inscripción, por lo tanto, una marca de identidad. Ello es así gracias a un capitel recientemente subastado en Madrid, adquirido por el Estado y que se conserva en el Museo Arqueológico Nacional, donde tiene el número de inventario $2001 / 151 / 1^{6}$.

Se trata de un capitel de orden compuesto, hecho en mármol blanco $^{7}$. Está magníficamente tallado con decoración vegetal y contario. Una de las cuatro cartelas de su ábaco ostenta la siguiente leyenda:

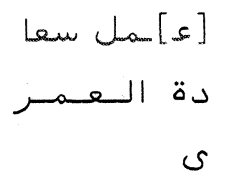

Es decir: «[O]bra de Sa‘āda al-‘Āmirī».

Como puede verse en el dibujo adjunto, está escrita con talla excisa, en caracteres cúficos simples, abarcando hasta apurar la totalidad del espacio disponible. Tanto es así, que «Sa'āda» ha tenido que divi-

${ }^{4}$ Véanse las citadas referencias de Rodríguez y Souto, así como Souto, J. A., "Glyptographie omeyyade: signes lapidaires à la Grande Mosquée de Cordoue. Documentation de noms propres", Actes du XIIe Colloque International de Glyptographie de Saint-Christophe-en-Brionnais, Braine-le-Château (2001), 283 y 295. Sobre el concepto de "marca de identidad", véase Van Belle, J.-L., "Les signes lapidaires: essai de terminologie", Actes du Colloque International de Glyptographie de Saragosse, Braine-le-Château (1983), 29-43, passim.

5 Souto, "Glyptographie", 295.

${ }^{6}$ Debemos a nuestro buen amigo D. Tawfiq Ibrahim nuestra primera noticia de este capitel y el dato de la subasta, que había tenido lugar el 12 de diciembre de 2001 en la conocida empresa madrileña "Fernando Durán". El día 28 de enero de 2002 nos dirigimos a ella, donde el Sr. Durán, $D^{a}$ Patricia Dueñas y $D^{a}$ Ana Martínez nos dieron información precisa del paradero de la pieza y nos facilitaron un ejemplar del catálogo de la mencionada subasta, en el que figuran una descripción del capitel en cuestión (p. 34) y fotos suyas de conjunto y de detalle (pp. 34-5 y contraportada). Acto seguido nos dirigimos al Museo Arqueológico Nacional, donde nuestra colega Ángela Franco nos facilitó el acceso a la pieza y la toma de los datos que figuran en este trabajo. Desde aquí agradecemos públicamente la gentileza de todos los mencionados.

${ }^{7}$ Medidas en centímetros: altura total: 25 ; longitud del ábaco: 27,5; diámetro de la base: 14 . Cartela: base: 6 ; lado superior: 6,5 ; altura: 3,8 . 
dirse entre dos líneas; no se ha hecho expresión gráfica de la /ā/ de «al-'Āmirī»; y la $y \bar{a}$ ' final de esta última palabra aparece en una tercera línea, bajo la dāl de «Sa‘āda». Son tres «peculiaridades gráficas» nada sorprendentes en este contexto. Cabe destacar, sin embargo, el

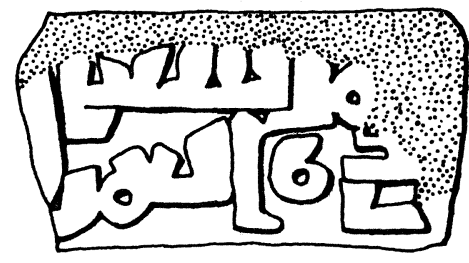

Inscripción del capitel n 2001/151/1 del Museo Arqueológico Nacional (Madrid)

remate inferior de la alif de «Sa‘āda», que se hace introduciéndose hacia la derecha por debajo del renglón.

Evidentemente, nos encontramos ante el autor de la pieza, un individuo llamado Sa'āda y que sería siervo o mawlà de Muhammad $b$. Abī 'Āmir, Almanzor, de ahí su nisba, «al-'Āmirī» ${ }^{8}$. La pieza del Museo Arqueológico Nacional quedaría así datada muy probablemente en su etapa de gobierno, 976 a 1002. No es el único caso conocido de «firma» de un trabajador de la construcción con esta nisba, ya que en la última ampliación de la Mezquita Aljama de Córdoba hay cinco fustes firmados por Jalaf al- 'Āmirī ${ }^{9}$; y en el Puente de Alcántara de Toledo hubo una inscripción, fechada en 387/4 enero 997-2 enero 998, donde Jalaf b. Muhammad al-'Āmirī figuraba como «director» de sus obras ${ }^{10}$.

Por todo ello creemos que el Sa'āda de los capiteles de la Mezquita de Córdoba puede ser identificado con este Sa'āda al-'Āmirī del del Museo Arqueológico Nacional, zanjándose además la duda de si

\footnotetext{
${ }^{8}$ Tampoco habría que descartar totalmente la posibilidad de que la tal nisba se refiera a alguno de los dos hijos y sucesores de Almanzor, aunque la consideramos remota.

9 Rodríguez y Souto, "De Gliptografia", fustes B18, D17, F31, G27 y H31. A ellos hay que sumar tres fustes y un cimacio firmados por Jalaf a secas, de quien no sabemos a ciencia cierta si sería el mismo: Ídem, fustes E4, F4 y G9, cimacio B20s.

${ }^{10}$ Rodríguez, $\mathrm{M}^{\mathrm{a}}$ J., y Souto, J. A., "De Almanzor a Felipe II: la inscripción del Puente de Alcántara de Toledo (387 / 997-998) y su curiosa historia", Al-Qanțara, XXI (2000), 185-209.
} 
estamos ante un onomástico o un vocablo propiciatorio a favor de lo primero. Más difícil sigue siendo, sin embargo, la identificación de este personaje con el Sa'āda que aparece como «coautor» de obras, junto con Mūsà b. 'Alī al-Bannā' (o al-bannā'), en la inscripción fundacional de la mezquita toledana de Bāb al-Mardūm, fechada en el mes de muharram de 390/13 diciembre 999-11 enero $1000{ }^{11}$.

11 Souto, "Glyptographie", p. 295. Sobre la inscripción: Ocaña Jiménez, M., "La inscripción fundacional de la mezquita de Bīb al-Mardūm en Toledo", Al-Andalus, XIV (1949), 175-83, donde se recoge su historiografia; y del mismo autor, El cúfico hispano y su evolución, Madrid (1970), $\mathrm{n}^{\circ}$ 28. Sobre la mezquita, véanse las intervenciones de C. Ewert y G. King en Larriba, M. A., coord., Entre el Califato y la Taifa: Mil años del Cristo de la Luz, Toledo (2000), 11-52 y 269-86, respectivamente. 